\title{
THE
}

\section{Financial education and insurance advice seeking}

Jing Jian Xiao

University of Rhode Island, jjxiao@uri.edu

Nilton Porto

University of Rhode Island, nilton_porto@uri.edu

Follow this and additional works at: https://digitalcommons.uri.edu/hdf_facpubs

The University of Rhode Island Faculty have made this article openly available.

Please let us know how Open Access to this research benefits you.

This is a pre-publication author manuscript of the final, published article.

Terms of Use

This article is made available under the terms and conditions applicable towards Open Access

Policy Articles, as set forth in our Terms of Use.

Citation/Publisher Attribution

Xiao, J.J. \& Porto, N. Geneva Pap Risk Insur Issues Pract (2018). https://doi.org/10.1057/

s41288-018-0108-1

Available at: https://doi.org/10.1057/s41288-018-0108-1

This Article is brought to you for free and open access by the Human Development and Family Science at DigitalCommons@URI. It has been accepted for inclusion in Human Development and Family Science Faculty Publications by an authorized administrator of DigitalCommons@URI. For more information, please contact digitalcommons-group@uri.edu. 


\title{
Financial Education and Insurance Advice Seeking
}

\author{
Jing Jian Xiao, Ph.D. \\ Corresponding Author \\ Professor of Consumer Finance \\ xiao@uri.edu \\ Nilton Porto, MBA, Ph.D. \\ Assistant Professor of Consumer Finance \\ nilton_porto@uri.edu \\ Department of Human Development and Family Studies \\ University of Rhode Island \\ 2 Lower College Road \\ Kingston, RI 02881, USA
}

Jing Jian Xiao, Ph.D., is a professor of consumer finance in the Department of Human Development and Family Studies at the University of Rhode Island. He has published many research papers in consumer finance journals and books including Handbook of Consumer Finance Research and Consumer Economic Wellbeing. He received his Ph.D. in consumer economics from Oregon State University.

Nilton Porto, Ph.D., is an assistant professor of consumer finance in the Department of Human Development and Family Studies at the University of Rhode Island. He received his MBA from Case Western Reserve University and Ph.D. in consumer science from the University of Wisconsin-Madison. 